\title{
Innovation Design Development of Citizenship Education Model on Characters of Indonesian Communities in Digital Media Era and Technology Revolution
}

\author{
Anita Trisiana
}

\begin{abstract}
Increasing independence and competitiveness of the nation is carried out in order to advance the Indonesian civilization. One of them is through the development of a national system of science, and technology in Citizenship Education. Citizenship Education is one of the subjects that shape the character of Indonesian society. The long-term goals to be achieved in this study are as follows: the researcher found a developmental design of Citizenship Education Learning Model to improve the character of Indonesian society in the era of digital media and the Revolution of Technology. The research method used research and development which is a research method used to yield certain products and to test the validity and the effectiveness of the products. This study used a procedural development model. The procedure in this study adapted the ADDIE model (Analyze, Design, Develop, Implement, and Evaluate). The sample in this study involved State and Private Universities in Indonesia. The results of the study show the following: First, doing a need analysis, identifying problems (needs), and performing task analysis; Second, Design, this design phase, formulated SMART learning objective; Third, Development was realizing blue-print with digital media innovation; Fourth, Implementation was a real step to implement the learning system that we were making; Fifth, Evaluation was a process to see whether the learning system being built was successful, in accordance with early expectations or not. The evaluation was the final way from the design model of the ADDIE learning system. Based on the instructional development model ADDIE, it was then adopted in the developmental stage of the Citizenship Education learning model, with the modification of "MPC" (Modification of Project Citizen) which has adopted the absorption of digital media and the technological revolution.
\end{abstract}

Index Terms: Design Development, Learning Models, Citizenship Education, Character, Digital Media, Technology Revolution.

\section{INTRODUCTION}

The issue on moral decadence either in individual, social, national or political life has already taken much attention of all components of the Indonesian nation. They are concerned that the weakening of the national character may be the threat for the existence of the Indonesian nation. Changes in structure should be followed by the development in education that may create the country's youth who are able to break the gap in social-economic structure. Education should be able to answer those strategic issues paradigmatically. Some practices in education in Indonesia to the present time are more focused on the development of skill and knowledge instead of on noble characters as well as nationalism. To the present time, it can be seen that the education in Indonesia tends to emphasize the intellectuality and neglect the morality.

Recently, a growing number of advanced digital technologies can be found easily. Development in digital technology brings some big changes to the world. People get some help in having some access to information through different channels and they can also access different facilities provided by digital technology liberally and deliberately. However, unfortunately, the more advanced the technology, the higher number of criminalism happens. Though digital revolution brings some big benefits to the society, some worries also come behind, particularly in the terms of the access towards information. The benefits are supported by the communication and information sharing that may develop the existing technology that may then lead to the rise of new technology that brings some potential for exploitation. Digital revolution helps the new era of mass surveillance to come, creating different civil and human right issues. Data reliability turns to be an issue since information can be replicated easily yet it is difficult to be diversified. Digital revolution allows facts, articles, and statistics to be searched and saved yet it leaves minutiae inadequate, to the present time.

Universities maintaining the character of Pancasila will enforce the character to the students. If the condition has been established, the universities may create the future generation possessing some characters required to build and prosper the nation. Character education is unique; it should take one's potentials into account to be an individual potential based education. Individual potential based character education is an education that not only guides but also trains students to have intellectual competence, mechanical, productive, and innovative skills as well as character building. 
The individual potential based character education is aimed at changing one's attitude from counterproductive to be creative. The Ministry of Education and Culture. (2013).

The following discussion on studies on different character education approaches is based on different approaches studied and put into a cleartypology by Superka, et. al. (1976). When Superka managed to accomplish his character education in his doctoral degree at the University of California, Berkeley, in 1973, he conducted a study and designed a typology as well as found different approaches in character education developed and used in education, particularly in high school level. His study reveals eight value education approaches derived from different literature in psychology, sociology, philosophy and education related to values. After some discussions with educators as well as practical reasons in its use in real field, those approaches are then simplifized into five typology approaches including (1) inculcation approach, (2) cognitive moral development approach, (3) values analysis approach, (4) values clarification approach, and (5) action learning approach.( Superka,et.al 1976).

The efforts in establishing the implementation of the character education is in line with the technology revolution movement program. The movement is getting more relevant with the mental revolution movement for Indonesia which is facing three main national problems including: the decrease in national pride, the intolerance spreading widelyas well as the weakening national economic aspects. It can clearly be seen in the following table:

Table I. The Implementation of Character Education in Universities

\begin{tabular}{llll}
\hline Activity & $\begin{array}{l}\text { Feasibility } \\
\text { Percentage }\end{array}$ & $\begin{array}{l}\text { Digital } \\
\text { Media }\end{array}$ & $\begin{array}{l}\text { Technology } \\
\text { Revolution }\end{array}$ \\
\hline $\begin{array}{l}\text { Freshman } \\
\text { Orientation }\end{array}$ & $40 \%$ & $20 \%$ & $20 \%$ \\
All Courses & $20 \%$ & $25 \%$ & $30 \%$ \\
Scout & $30 \%$ & $30 \%$ & $10 \%$ \\
Regulations & $10 \%$ & $25 \%$ & $40 \%$ \\
\hline
\end{tabular}

Source: Trisiana, (2015)

Based on previous studies the researcher conducted under competitive grantas well as disertation grant shcemes (Trisiana, 2015), it is known that "universities have a strategic role in the implementation of character building, integrated in the implementation of teaching learning process." The studies show that there should be some follow ups in terms of teaching learning innovation, i.e. by developing character education based teaching learning model (Trisiana, 2016). Besides, the evaluation towards the implementation of General Education as the development unitforpersonalities in different universities disscussed in Focus Group Discussion (February, 2017), shows that:First, Technical Executing Unit of General courses in each university should make some breakthrough in the development of teaching learning activities that can strengthen the character of the university. Second, pertaining to the implementation of the sustainable character education, students joining the general courses still complained that almost $70 \%$ of the character education model the lecturers emphasized and delivered is still theoretical, which means that creativity, skills in citizenship and responsibility are still limited to knowledge aspect (text book), so that the achievement for Attitude aspect is about $30 \%$ which means that it is still low. Third, $73 \%$ of the Lecturers require some assistancy in finding, implementing and evaluating nationalism based national character education model, it is expected that $27 \%$ of those who have implemented character education in universities can be more sharply improved to give some basic education, skill and learning experience that can build social integrity and create some national characters explored from many local wisdom values.

Technology revolution has changed one's point of view in living his sophisticated life. Technology brings some big changes to the world. It either provides some helps in every single activity or creates some problems due to the in ablility in using sophisticated digital facility properly. Therefore, national independency and competitiveness can be reached in a condition that it is conducted toadvance the Indonesian civilization. One of the efforts is through the development of national system of science and technology in Citizenship Education. Citizenship Education is one of the subjects that can build Indonesian characters. Long term objetives the study aimed to achieve is to find a development design in Citizenship Education teaching model in order to build Indonesian Characters in digital media and Technology Revolution Era.

\section{LITERATURE REVIEW}

The terms of instructional system development and instructional design are often overlapped or at least cannot be firmly distinguished in terms of the usage though there are some differences in their definition, i.e. the definitions of "design and "development". "Design" refers to the action in making a sketch or pattern or outline or prior plan. While "development" is growing something steadily to be bigger, better, more effective, etc (Harjanto, 2008 : 95). Instructional system development is a systematic and logic process in studying different teaching learning problems to have some solutions which are reliable and practical to do. Instructional System is all learning materials and methods whis have been practically proven and prepared to reach different real objectives. In other words, it can be said that instructional system refers to the system used in teaching learning activities. It encompasses the need analysis process, the learning objectives and the development of teaching method as well as teaching materials used to meet the needs. It also includes the development of teaching learning package, teaching activities, test, revision and the evaluation towards learning outcome. 
Instructional system design is a systematic approach in planning and developing media and resources taken in achieving the needs and instructional objectives. This entire system concept (objective, material, method, media, resources, and evaluation) is considered as a systematic regular unit. The effectivity of the components is previously tested before it is published. The development of the system is a process of deciding and creating a situation and conditions that can make students interact to some extent so that their attitudes may change (Joyce: 2009). Teaching learning design is a discipline related to the understanding and improvement towards an aspect in education, i.e. teaching learning process. The objective of composing a teaching learning design is to create optimum media used to reach the intended teaching learning objectives. Therefore, the discipline mainly relates to the development of teaching learning methods leading to some intended changes in students' knowledge and skills.

Mayer, RE (2008) States that education requires "linking science" between learning theories and the practice. Teaching learning design is taken as the link between the two aspects since it is the science that is used to develop teaching learning actions in achieving the teaching learning outcome. The design aspect covers two main areas including (1) psychology, particularly learning theories, and (2) media and communication. However, likely, media and communication give some principle and strategic contributions to the design discretely, unlike learning theories that may give an integrated model. Teaching learning design has more support from learning theories.

Rauner and Maclean (2008: 49) convey that model is "An alternative for a system which is actually aimed for an experiment". From the definition it can be concluded that model is a representative or abstraction of an object or actual situation showing either direct or indirect link as well as are ciprocal link in the term of cause effect. Teaching learning model is the basis for the teaching learning practice derived from educational psychology theories as well as learning theories developed based on the analysis towards the implementation of curriculum as well as its implication in the operational level, in a class.

Joyce, Weil \& Calhoun (2011:31) say that : there are four model clusters including The Information Processing Models,Personal Models,Social Models and Behavioral Systems group. The four clusters above have the following aspects: 1) Syntax, steps in teaching that refer to the phases/steps to be carried out by teachers when they use a particular teaching learning model. For instance, deductive model may require a syntax different from that of inductive model; 2). Principles of Reaction, an activity pattern depicting how teachers should see and treat students, including how the teachers should give some response towards the students. These principles give some guidance on how a teacher should use the rules of game of any model; 3) The Social System, teacher student relationship pattern within teaching learning process (a situation or condition and prevailing norm swhich are in accordance with a certain teaching learning model); 4). Support System,all media, material and resources required to support an optimum teaching learning process; and 5). Instructional Effect and Nurturant Effects, Jeannie, B. L. (1997). Instructional effect is the learning outcome achieved or related directly to teaching learning material while nurturant effect is the nurturant learning outcome ahieved as an effect of the use of a particular teaching learning model.

The vision of Citizenship Education in university is to be the source of values as well as guidelines in the development and the management of study program, to lead the students to establish their personality as human being. The mission is to help students to establish their personality, so that they can consistently realize the basic values of Pancasila, nationalism, and patriotism in mastering, implementing and developing sicence, technology and arts with all responsibilities and moral standards. Therefore, citizenship education in Indonesia has also had some important contribution in supporting the objectives of Indonesia as a nation. Citizenship education systematically is the representation of the function and the objectives of national education under Pancasila and the National Constitution of the Republic of Indonesia 1945. Citizenship education relates to and supports the development of the life of people and nation.

Citizenship education is an integral part of the idea, instrumentation, and practice of social, national and political life of Indonesia (Udin Winataputra, 2008). Even, it is said that our national education basically is citizenship education aimed at having a qualified Indonesian in either social and national discipline, work performance, work productivity, intellectual and professional ability, social, national, and human responsibility, moral, character or personality (Soedijarto, 2008). Citizenship education is cross disciplinary field (Udin Winataputra, 2001) or multidimensional field (Sapriya, 2007). As a multidimensional field, citizenship education can cover a number of functions including the functions as political education, law education and value education (Numan Somantri, 2001); democratic education (Udin Winataputra, 2001); value, democratic, moral and Pancasila education (Suwarma, 2006),state law and politic education in the citizenship of the country and nation of the Unitary State of the Republic of Indonesia (NKRI), as the education towards moral values of Pancasila and the Constitution of NKRI, citizenship education of NKRI and as civic education of NKRI (Kosasih Djahiri, 2007); and as democratic education, national character education, value and moral education, state defense education, political education, and law education (Sapriya, 2007). Those different functions are in line with the characteristics of "good citizens" to build.

Lickona, T. (2004:2) states that "character is made up of core etical values that incorporate ones thought process, emotion and action". Brown, Chamberland and Morris further state that there are 8 basic characters to develop including honesty, courage, respect, responsibility, perseverence, cooperation, self-control and citizenship. 
The followings are the Character First agreed to be the minimum characters to be developed in the teaching and learning carried out in Indonesia. The 49 characters are as can be seen in Table II.

Table II. Minimum Characters to be developed in Teaching Learning Process

\begin{tabular}{|c|c|c|c|}
\hline \multicolumn{4}{|c|}{ Character Quality } \\
\hline Alertness, & Diligence, & Humility, & Security, \\
\hline Attentiveness & Discernmen & Initiative, & Self-Control, \\
\hline & $\mathrm{t}$ & Joyfulness, & Sensitivity, \\
\hline Availability, & Discretion, & Justice, & Sincerity, \\
\hline Benevolence, & Endurance, & Loyalty, & Thoroughnes \\
\hline Boldness, & Enthusiasm, & Meekness, & $\mathrm{s}$ \\
\hline Cautiousness & Faith, & Obedience, & Thriftiness, \\
\hline & Flexibility, & Orderliness, & Tolerance, \\
\hline Compassion, & Forgiveness & Patience, & Truthfulness, \\
\hline Contentment, & & Persuasiveness, & \\
\hline Creativity, & Generosity, & Punctuality, & Virtue, \\
\hline Decisiveness & Gentleness, & Resourcefulnes & Wisdom, \\
\hline Deference, & Gratefulnes & $\mathrm{s}$ & \\
\hline Dependabilit & $\mathrm{s}$ & Responsibility, & \\
\hline & Honor, & & \\
\hline $\begin{array}{l}\text { Determinatio } \\
\mathrm{n}\end{array}$ & Hospitality, & & \\
\hline
\end{tabular}

Source: The Ministry of Education and Culture, (2013).

Digital media is media coded in a machine-readable form. Digital media use binary concept of 0 and 1 with discrete wave. Digital media can be made, seen, distributed, and modified as well as run in digital electronic devices. Digital processes use Algorithm logics. Computer and software programs like digital imaging, digital video; video games; web page and website, including social media; data and database; digital audio like mp3, mp4 and e-book are some of the digital media. Digital media is extremely different from analog media that rely on manual system like printed media, printed book, newspaper and magazine which are still traditional like picture, movie, tape audio, etc.

Modern era of the combination of internet and personal computation leads digital media to have some effects and be an issue in publishing, journalism, entertainment, education, trade and politics. Digital media has also caused some new challenges particularly for the law that protects copy right and the intellectual property in an open content movement where the content creator voluntarily gives all or some of their legal rights for their work. Digital media has now entered social life aspects and brought some effects to the society and it shows that digital media is the beginning of a new era in industrial history called as Information era leading to the paperless society where all information products found in media are produced and consumed in computer base. However, the challenge in entering the transition of digital media including some legal products regulating copy right, censor, and digital divide are some issues that should be faced towards the digital dark age where the older media cannot be either accessed to the new system or upgraded to the information system.

However, significant, varied and complex digital media has given some impacts to the society and the culture.
Revolution refers to the basic changes in different fields which run fast and relate to the social life basis or aspects. The speed level of the changes is relative since revolution also takes time. Revolution is aimed at breaking the old system to be a new one. However, technology is science or knowledge on useful skills. From the definition, it can be said that technology is born due to a condition insisting humans to meet a certain needs. Therefore, technology revolution is some drastic social changes in significant structures which run relatively fast as the result of the technological invention.

\section{METHODOLOGY}

This study was conducted in all state/private universities in Central Java. This study is a research \& development study. Gall, Gall, and Borg (2007: 569)defines Educational R \& D as follow: Educational Research and Development (Educational R \& D) is an industry-based development model in which the findings of the research are used to design new products and procedures, which then are systematically field-tested, evaluated, and refined until they meet specified criteria of effectiveness, quality, or similar standard. It is described by Borg Gall (1989: 772) that the term of product is referred to not only the material objects like text book, teaching learning movie, etc. but also procedure and process like teaching learning method or the method for organizing teaching and learning process. Therefore, this Study is categorized as research \& development study which refers to a study aimed at developing a model, either hardware or software.(Sukmadinata, Nana Syaodih: 2015).

The data collected are comprised by primary and secondary data. Primary data refer to the information on informant, site and event (through site inspection). The informant consists of citizenship education lecturers as well as the students taking the course in the even semester of 2018/ 2019. The data were collected using different methods including : participant observation; FGD (Focus Group Discussion); in-depth interview; documentary study. The sampling technique used in this study was purposive sampling. The analysis technique used in this qualitative study is based on the Interactive Analysis Model (Miles \& Huberman, 1992). According to this model, in collecting data, researchers should at all times make some data reduction and perform the data continuously until they lead to a conclusion.

\section{RESULTS AND FINDINGS}

Citizenship Education in universities has an important role in the education process where it can explore all individual potentials cleverly and effectively for the sake of a society financially and materially satisfied. Therefore, there should be some improvement/reformation in the concept and paradigm of Citizenship Education from a condition emphasizing the cognitive aspect to the condition emphasizing the development 
of smart, democratic, and religious citizens with multi dimensional characteristics. Reformation in the teaching and learning process of citizenship education is expected that it can make students to be a smart, creative, participative, prospective and responsible young citizen so that they are able to give some recommendation towards public policies in their neighborhood. From the above explanation, it can be seen that to the present time, the teaching and learning process in Citizenship Education more emphasizes cognitive aspect instead of the affective one (Narvaez, Bock, Lies: 2004)

The teaching and learning process in Citizenship Education should cover three aspects of cognitive, affective, and psychomotor. Therefore, it requires some improvement in terms of value internalization and individual character. Preliminary study is aimed at describing the design for the development of citizenship education teaching learning model, the problems increased as well as the needs in teaching learning model design aimed at building the students' character and designing a draft for teaching learning model of character education. The draft is developed in reference to the model components which include: teaching learning step, teaching model, teaching learning principles, supporting system, as well as instructional and nurturant effects. The activities conducted in achieving the objectives include some literature studies as well as some small scale studies which are then reviewed in a meeting attended by experts. Literature study and field survey are used to compose an initial draft design which may further be reviewed in a meeting of experts. It is based on the meeting that the researcher further develops the draft for development design. The revised draft is then copied as needed.

Table III. Students' Comment on Character Education at Slamet Riyadi University, Surakarta

\begin{tabular}{lll}
\hline Component assessed & $\begin{array}{l}\text { Score } \\
\text { Average }\end{array}$ & $\begin{array}{l}\text { Score } \\
\text { Percentag } \\
\text { e Average }\end{array}$ \\
\hline $\begin{array}{l}\text { INTELLECTUAL ATTITUDE } \\
\text { Attentiveness }\end{array}$ & 3.15 & $63 \%$ \\
Analyticity & 3.24 & $64.8 \%$ \\
Anticipative & 3.41 & $68.2 \%$ \\
Cautiousness & 3.35 & $67 \%$ \\
SPIRITUAL ATTITUDE & & \\
Firmnessand Confidence & 3.65 & $73 \%$ \\
Availability & 3.5 & $70 \%$ \\
Benevolence & 3.53 & $70.6 \%$ \\
SOCIAL ATTITUDE & & \\
Loving & 3.41 & $68.2 \%$ \\
Courage & 3.53 & $70.6 \%$ \\
Compassion & 3.5 & $70 \%$ \\
\hline
\end{tabular}

The procedural steps taken by the researcher is the one with

ADDIE

(Analysis-Design-Develop-Implement-Evaluate).

Designing is the second step of the MPC which includes: determining learning experience the students should have after the course, whether MPC teaching learning program can solve the problem of the gap in students' ability Students are able to reach the $60 \%$ competence of the standard of competence, indicator, teaching learning condition, determined teaching material. Development is the third step in the implementation of MPC teaching learning model, including the activities of choosing, determining teaching learning method, media and strategy to be used in delivering materials and basic competence to achieve. The next step is the implementation or delivery of the teaching learning material which belongs to the forth step of the MPC teaching learning model, guiding students to reach their objective or competence. The next is ensuring the problem solving in bridging the gap in the students' learning outcome and the last is ensuring that at the end of the program, students should have some required knowledge, attitude and skill competences related to the character values in civic knowledge, civic skill and civic disposition aspects. Therefore, several steps are established including (Trisiana, 2015: 124):(1) Explainingsome information in reference to the basic competence (2)Identifying character value based problems (3) Determining a problem to be discussed by a class based on character values; (4) Collecting some information pertaining to the problem; (5) Developing value a class portfolio under the character value basis; (6) Presenting portofolio; (7) Doing some reflection towards learning experience under character value basis. The evaluation phase in the forth step is conducted through formative evaluation since it is aimed at meeting theneed for revision. The evaluation towards MPC teaching learning program is aimed at finding the students' attitude towards teaching learning activities, the development of the students' competences, which is also the effect of the participation in the teaching learning program

The development of science and technology from the west brings some effects to the development of Indonesia. Indonesian society had once begun the movement to struggle for Indonesian independence and the use of science and technology in Indonesia brings some patriotism to the nation. They used the modern science and technology to find some recent information on the global condition. Thus, Indonesia was indeed helped by the development of science and technology (Nasrullah R.: 2016)

Under colonialism, the development of science and technology was not optimum. It was the colonial government who brings the development of the science and technology to Indonesia. The colonial government closed the access for science and technology from the west to Indonesia. They also forbid Indonesian to study science and technology. Consequently, Indonesia was far left behind from the neighboring countries. In general, the other reasons for the backwardness of Indonesia in science and technology are as follows : (a) Indonesian pursuing education particularly higher education were still low in number, (b) Indonesian occasionally involved directly in the development of science and technology, (c) The Dutch government and companies in Indonesia did the technology revolution, (d) Industrialization was still minimum, and (e) Indonesian 
society was still lack of significant technological innovation. After the independence, science and technology developed very fast in Indonesia. It was supported by the access towards the science and technology for the Indonesian. The independence creates some justice and access to science and technology for the people.

It was due to knowledge that Indonesian then did some innovations and experiments in science and technology to develop the science in Indonesia. Life much changed from the past. Nowadays, distance and time are not a big problem for the economy, different applications are created to facilitate it. Economy of a country can be seen from its development in information and communication technology The higher the information technology, the higher the development of economy in the country. However, the development of information technology has also some negative effects that a number of technological misuses happened and it was related to criminalism. Technological advancement is a condition that cannot be avoided in our life since the improvement will keep going following the development of science.

Innovation is created to give some positive benefits for human life. It gives some access and it is taken as a new way in doing something for human. In terms of technology, people have undeniably received a number of benefits brought by some innovations in the last decades. However, though it was initially created to bring some positive benefit, it is also possible to be used for negative things.

Table IV: Development of the Teaching Learning Model Modification of Project Citizen using ADDIE Model

\begin{tabular}{|c|c|}
\hline $\begin{array}{l}\text { Digital } \\
\text { Media } \\
\end{array}$ & $\begin{array}{l}\text { Teaching Learning } \\
\text { Activities }\end{array}$ \\
\hline 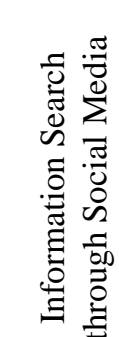 & $\begin{array}{l}\text { Reading, Listening, } \\
\text { and observing(with or } \\
\text { without devices) } \\
\text { Source: Youtobe; } \\
\text { Facebook; WhatsApp } \\
\text { Instagram }\end{array}$ \\
\hline
\end{tabular}

Asking for questions on some information Technology and Characters developed they do not understand ability in building critical after some observation minds required for smart or for the ones required life and long life learning for having some additional information on the observed object (including factual and hypothetical questions) :Students make some Instrument of guidance for interview and observation facilitated by lecturers in a class.

Training determination, patience, thoroughness and ability in distinguishing general and specific information, analytic, critical, deductive and comprehensive thinking skill

Developing creativity, curiousity, questioning ability in building critical
minds required for smart
-Doing an experiment -Reading other sources, other that text books -observing object/event/ activity -interview with resource person in accordance with respective location -Processing some information collected either from the collecting/experimenti ng activities or from observing and collecting information activities

- Processing information that can broad or deepen the knowledge or the one for problem solving from different sources with different ideas. Presenting the report on observation, conclusion based on analysis either in spoken, written or using other media :

Making and interview field note .

Modifying,

recomposing in

finding some

innovation, and

finding some authentic innovation

\section{Lecturer along with}

students, and

Stakeholders do some

evaluation towards the

teaching learning outcome
Developing the attitudes of thoroughness, honesty, politeness, appreciating others' opinion, communication skill, implementing skills in collecting information through different ways studied, developing long life learning behavior.

Developing the attitudes of honesty, thoroughness, discipline, obedience, and hardworking, inductive and deductive thinking skill in making some conclusion. reflection towards

Developing the attitudes of honesty, thoroughness, tolerance, systematic thinking skill, giving some opinion effectively, and developing language skill properly

Creativity and honesty and appreciating other works as well as other nations.

Gaining some
alternatives for having
some draft of public
policy in solving some
problems in line with
underlying themes by
experts (education, law,
social)

\section{CONCLUSION}

The development design of Citizenship Education teaching learning model in developing the Characters of Indonesian in digital media era and Technology Revolution is carried out through Analyze, Design, Develop, Implement, Evaluation (ADDIE) covering: first Analysis, doing some need analysis, problem identification (need), and task analysis. 
Second, designing. In this step, SMART teaching learning objectives are developed. Third, Development, the process in realizing the blue-print. Forth, Implementation, the real step to implement the teaching learning system created. Fifth, Evaluation, the process to see whether the teaching learning system was succeed, in accordance with the prior expectation or not. Evaluation is the last step of ADDIE teaching learning system design model. It is based on ADDIE instructional development model that the phases in the development of Project Citizen (PC) teaching learning model called as "MPC" (Modification of Project Citizen)developed. The competence of Citizenship Education, particularly civic virtue cannot be separated form technology revolution, i.e. in understanding and implementing character values responsibility in Industrial Revolution era.

\section{ACKNOWLEDGMENT}

The writer would like to thank Directorate General of Strengthening for Research and Development of the Ministry of Research, Technology and Higher Education through International Seminar Grant program in 2019.

\section{REFERENCES}

[1] Harjanto. Lesson Plan (Perencanaan Pengajaran). Jakarta: Rineka Cipta, 2008.

[2] Jeannie, B. L. Student mentality: intentionalist perspectives about the principal. Journal of Educational Administration, 35 (3), United Kingdom: MCB UP Limited, 1997. pp. 210-233.

[3] Joyce, B \& Weil M. Model Of Teaching.Prentice- Hall, Inc: New Jersey, 2009.

[4] Joyce, Bruce, Marsha Weill, Emily Calhoun. Model Of Teaching (Alih Bahasa: Ahmad Fawaid dan Ateilla Mirza). Yogyakarta: Pustaka Pelajar, 2009.

[5] Kementerian Pendidikan dan Kebudayaan (The Ministry of Education and Culture). Policies in National Character Education (Kebijakan Pendidikan Karakter Bangsa). Jakarta: Kemendiknas, 2013.

[6] Lickona, T. Character Matters: How to Help Our Children Develop. New York: Simon \& Schuster, Inc, 2004.

[7] Lickona, T. Eleven Principles of Effective Character Education. Journal of Moral Education, 25(1), 2003. pp. 93-100.

[8] Mayer, RE. Leraning and Instruction. New Jersey: Pearson, 2008.

[9] Miles, B.B.,\& A.M. Huberman. Qualitative Data Analysis (Analisa Data Kualitatif). Jakarta: UI Pres, 1992.

[10] Narvaez, Bock, Lies. The Community Voieces And Character Education (CVCE) Project. Journal of Research in Character Education, 2, Bern, Switzerland: Peter Lang. 2004. pp. 89-112.

[11] Nasrullah R. Social media in communication, culture, and sociotechnology perspective (Media sosial perspektif komunikasi, budaya,dan sosioteknologi), Bandung : Simbiosa Rekatama Media, 2016.

[12] Sapriya, Experts' Perspectives on Citizenship Education in Building the National Characters (Persfektif Pemikiran Pakar Tentang Pendidikan Kewarganegaraan Dalam Pembangunan Karakter Bangsa). Bandung: Universitas Pendidikan Indonesia, 2007.

[13] Sukmadinata, Nana Syaodih. Educational Research Method (Metode Penelitian Pendidikan). Bandung: Program Pascasarjana UPI dan PT Remaja Rosdakarya, 2015.

[14] Superka, D.P. A typology of valuing theories and values education approaches. Doctor of Education Dissertation.University of California, Berkeley., 1973.

[15] Suwarma. Micro Teaching, Practical Approach in Preparing Professional Educators (Pengajaran Mikro, Pendekatan Praktis dalam Menyiapkan Pendidik Profesional). Yogyakarta: Tiara Wacana, 2006.

[16] Trisiana, A. The Development Strategy Of Citizenship Education in Civic Education Using Project Citizen Model in Indonesia. Journal of Psychological and Educational Research (JPER), 23 (2), 2015. pp. 111-124.

[17] Trisiana, A. Analysis Of Character Education Policy In Indonesian School To Improve The Asean Economic
Community. Research Journal of Applied Sciences (RJAS), Volume 11 (9), pp. 879-883. 2016.

\section{AUTHOR PROFILE}

My Name is Anita Trisiana, working with Faculty of Teacher Training, Slamet Riyadi University Surakarta, Indonesia, my area of interest is education and training.anita.trisiana@gmail.com 